DOROTA MAJKA-ROSTEK

Uniwersytet Wrocławski

\title{
Prawa mniejszości seksualnych w Polsce
}

DOI: 10.19195/2083-7763.8.11

\section{Wprowadzenie}

Artykuł dotyczy działań polskiego ruchu LGBT i specyfiki sytuacji osób nieheteroseksualnych w społeczeństwie polskim. Kwestie te ujęte są w kontekście problematyki praw obywatelskich, których elementem są prawa seksualne. Wstępem do opracowania jest krótka prezentacja koncepcji obywatelstwa seksualnego. Następnie przedstawiono zarys historii aktywności organizacyjnej działaczy LGBT w Polsce, ujmowanej jako walka o trzy zasadnicze prawa: prawo do zawierania związków, prawo do rzetelnej edukacji i prawo do ochrony przed dyskryminacją i mową nienawiści. Od dwudziestu pięciu lat te postulaty pozostają niezmienne, gdyż żadne $\mathrm{z}$ owych praw nie zostało jak dotąd zagwarantowane mniejszościom seksualnym.

\section{Obywatelstwo seksualne}

Obywatelstwo jest pojęciem, którego różnorodne znaczenia ukształtowały się w toku rozwoju historycznego. W najbardziej ogólnym ujęciu dotyczy specyfiki więzi między jednostką a państwem. Współczesne rozumienie obywatelstwa wychodzi najczęściej poza starożytne ujęcie polityczne (Grecy) i formalnoprawne (Rzymianie), dołączając do nich obszary praw osobistych oraz socjalnych. Wieloznaczność terminu „obywatelstwo” można próbować uporządkować poprzez wyodrębnienie czterech podstawowych sposobów jego ujmowania: jako prawo, status formalnoprawny, zaangażowanie polityczne i tożsamość ${ }^{1}$. Obecnie

${ }^{1}$ D. Pudzianowska, Obywatelstwo w procesie zmian, Warszawa 2013. 
obywatelstwo opatrywane jest dodatkowo określeniami typu: kulturowe, etniczne, zdrowotne czy seksualne. Koncepcja obywatelstwa seksualnego (sexual citizenship) pojawiła się w analizach polityczno-społecznych wraz tendencjami do problematyzowania i kwestionowania zasadności dychotomii prywatne/polityczne. Wprowadzenie w obszar publiczny kwestii tradycyjnie uznawanych za prywatne wiązało się z umiejscowieniem ich w kontekście praw i obowiązków obywatelskich. Wielu autorów zajmujących się problematyką obywatelstwa seksualnego wychodzi z założenia, że sam konstrukt obywatelstwa jest oparty na hegemonicznej seksualności - modelowy „obywatel” to biały, heteroseksualny mężczyzna ${ }^{2}$. W tej perspektywie obywatelstwa nie można odseparować od kwestii ludzkiej seksualności - obywatelstwo jest nierozerwalnie połączone z tożsamością, a seksualność stanowi kluczowy element tożsamości ${ }^{3}$. Współczesne rozumienie pojęcia obywatelstwa seksualnego przejawia się $\mathrm{w}$ dwóch zasadniczych podejściach. Pierwsze odnosi się do konkretnych praw seksualnych, gwarantowanych lub odmawianych różnym grupom społecznym. Drugie podejście jest szersze i skupia się na tym, jak różnorodne formy statusu obywatelskiego zależą od seksualności. W tej perspektywie barierą realizacji praw obywatelskich mniejszości seksualnych jest zjawisko heteronormatywności, czyli dominacji wzorców, które zakodowane są w języku, w instytucjach społecznych i w codziennych praktykach społecznych, legitymizujących i uprzywilejowujących heteroseksualność. Uprzywilejowanie heteroseksualności polega na traktowaniu jej jako właściwej, naturalnej i normalnej oraz nie wymagającej żadnych wyjaśnień formy ludzkiego funkcjonowania ${ }^{4}$. Sama koncepcja obywatelstwa ma charakter heteronormatywny, dlatego osoby nieheteroseksualne są wykluczane $\mathrm{z}$ obszaru oddziaływania wielu praw obywatelskich (w zależności od społeczeństwa może to być prawo do małżeństwa, prawo do służby wojskowej, prawo do ochrony przed dyskryminacją itp. $)^{5}$.

Diane Richardson uważa, że jeśli konceptualizujemy obywatelstwo seksualne, używając modelu praw i obowiązków, musimy zadać pytanie, czym są prawa seksualne $e^{6}$. Sposób definiowania tych praw zależy między innymi od rozumienia seksualności. Najczęściej można spotkać się z odnoszeniem praw seksualnych do: orientacji seksualnej, tożsamości genderowej, relacji intymnych, praktyk erotycznych, zdrowia, reprodukcji, integralności cielesnej, autonomii ${ }^{7}$. Zdaniem Richardson obywatelstwo seksualne sytuuje prawa seksualne $\mathrm{w}$ trzech zasadniczych obszarach. Są to:

\footnotetext{
${ }^{2}$ K. Plummer, Intimate Citizenship: Private Decisions and Public Dialogues, Seattle-London 2003.

3 D. Bell, J. Binnie, The Sexual Citizen: Queer Politics and Beyond, Cambridge 2000.

${ }^{4}$ M. Warner, Introduction, [w:] Fear of a Queer Planet, red. M. Warner, Minneapolis 1993.

5 D. Richardson, Rethinking Sexuality, London-New Delhi 2000.

6 D. Richardson, Constructing sexual citizenship: Theorizing sexual rights, „Critical Social Policy” 20, 2000, nr 1, s. 105-135.

7 A. Wilson, The transnational geography of sexual rights, [w:] Truth Claims: Representation and Human Rights, red. M.P. Bradley, P. Petro, New Brunswick 2002, s. 251-265.
} 
— różnorodne formy praktyk seksualnych;

- indywidualne identyfikacje i strategie tożsamościowe;

- instytucje społeczne i ich stosunek wobec różnych form relacji seksualnych.

W odniesieniu do tych trzech obszarów Richardson określa obywatelstwo seksualne jako system praw dotyczących seksualnych zachowań, tożsamości oraz relacji ${ }^{8}$. To, na jakie prawa kładą nacisk w swoich postulatach aktywiści ruchów mniejszości seksualnych, zależy od specyfiki danego społeczeństwa. Są jeszcze kraje, w których stosunki homoseksualne są karalne, z karą śmierci włącznie. Istnieją także państwa, które umożliwiają parom jednopłciowym zawieranie małżeństw i adopcję dzieci. W zależności od miejsca walka o realizację praw seksualnych może dotyczyć dążenia do depenalizacji stosunków homoseksualnych, możliwości publicznych manifestacji czy też różnych aspektów symbolicznego uznania nieheteroseksualnych tożsamości i stylów życia. W 2002 roku Światowa Organizacja Zdrowia (WHO) przyjęła i zarekomendowała Powszechną Deklarację Praw Seksualnych ${ }^{9}$. Wymienionych tam kilkanaście praw seksualnych opiera się na założeniu, że seksualność jako integralna część każdego człowieka ma wymiar nie tylko indywidualny, lecz także interpersonalny oraz społeczny. Wynika z interakcji pomiędzy jednostką a strukturą społeczną, w której jednostka funkcjonuje. Prawa seksualne zaliczane są przez autorów Deklaracji do uniwersalnych praw człowieka, opartych na niezbywalnej wolności, godności i równości wszystkich istot ludzkich.

\section{Ruch LGBT w Polsce}

Narodziny oficjalnego ruchu LGBT w Polsce miały miejsce na początku lat dziewięćdziesiątych XX wieku, co w oczywisty sposób wiąże się ze zmianą ustrojową. Jednak już dekadę wcześniej zaczęły powstawać nieformalne stowarzyszenia i inicjatywy, a w tzw. trzecim obiegu ukazywały się czasopisma funkcjonujące poza cenzurą, na zasadzie wydawnictw fanzinowych. Ten pionierski okres organizowania się gejów i lesbijek nie wiązał się jeszcze z wykorzystywaniem dyskursu praw. Oddolna działalność nastawiona była głównie na realizację celów wewnętrznych - towarzyskich, integracyjnych i tożsamościowych. Strategia wynikała z dostosowania się do warunków społeczno-politycznych. Z jednej strony powojenna Polska wyróżniała się liberalnym ustawodawstwem - utrzymano w niej obowiązujący od 1932 roku brak penalizacji stosunków seksualnych między osobami tej samej płci (w wielu krajach europejskich były one karalne aż do lat sześćdziesiątych ubiegłego wieku). Z drugiej strony w PRL homoseksualizm oficjalnie nie istniał, o czym pisze Krzysztof Tomasik:

\footnotetext{
8 Ibidem.

9 www.federa.org.pl/dokumenty_pdf/DeklaracjaPrawSeksONZ.doc (dostęp: 2.02.2017).
} 
Słowa gej faktycznie nie było, królował pedał, a sam temat średnio funkcjonował w świadomości społecznej. Pojedyncze książki, kilka filmów z ciotowskimi epizodami, dobrze ukryte kluby, artykuły w specjalistycznych pismach na temat zboczeń płciowych i kryminogennych środowisk $[\ldots]^{10}$.

Symbolem sytuacji osób nieheteroseksualnych była rozpoczęta w 1985 roku akcja „Hiacynt”. W jej ramach milicja przeprowadzała aresztowania homoseksualnych mężczyzn i zmuszała do wypełniania tzw. Karty homoseksualisty. Efektem tych działań było zgromadzenie kartotek z danymi ok. 11 tysięcy osób. Mimo że homoseksualizm nie był w PRL przestępstwem, homoseksualiści nie mogli wówczas liczyć na respektowanie jakichkolwiek praw obywatelskich, bywali zastraszani i szantażowani. Ryszard Kisiel, jeden z pierwszych działaczy gejowskich, wspominał te czasy następująco: „Niektórzy opowiadali, że milicjanci pojawiali się w ich domach i informowali rodziców, że "mają w domu zboka«. Albo informowali zakłady pracy i uczelnie"11. Symboliczna była data 23 lutego 1990 roku - zarejestrowano wtedy Stowarzyszenie Grup Lambda. Celem pierwszych oficjalnie działających organizacji było przede wszystkim zaistnienie w przestrzeni publicznej jako reprezentacja mniejszości społecznej, a także kwestie integracji i samopomocy środowiskowej.

Od lat dziewięćdziesiątych stopniowo przybywało organizacji działających pod szyldem praw LGBT, o charakterze zarówno ogólnopolskim (np. Kampania Przeciw Homofobii), jak i lokalnym (np. śląskie Stowarzyszenie Tęczówka). Jednym z narzędzi politycznych ruchu mniejszości seksualnych są organizowane systematycznie marsze i parady. W manifestach tych wystąpień powtarzają się najczęściej trzy postulaty:

- prawo do zawierania związków

- prawo do rzetelnej edukacji

- prawo do ochrony przed dyskryminacją i mową nienawiści.

Obecnie, po ponad 25 latach działalności polskiego ruchu LGBT, z pewnością można mówić o wielu zmianach sytuacji osób nieheteroseksualnych. Przede wszystkim przestały one być społecznie niewidzialne i symbolicznie anihilowane. Natomiast w kwestii zasadniczych praw, których realizacji domagają się przedstawiciele organizacji LGBT, zmiany z pewnością nie są satysfakcjonujące.

\section{Prawo do zawierania związków}

Możliwość prawnej rejestracji jednopłciowych związków partnerskich jest jednym z zasadniczych celów działalności polskiego ruchu LGBT. Począwszy od propozycji posłanki Joanny Sosnowskiej z 2002 roku, przez projekt ustawy złożonej

10 K. Tomasik, Gejerel. Mniejszości seksualne w PRL-u, Warszawa 2012, s. 7.

11 Ibidem, s. 41. 
w 2003 roku w Senacie przez Marię Szyszkowską, aż do projektów autorstwa Ruchu Palikota i SLD oraz posła PO Artura Dunina z 2012 roku - wszystkie próby realizacji tego celu kończyły się niepowodzeniem. Ostatnie projekty Sejm kilkukrotnie odrzucal - posłowie głosowali przeciw skierowaniu ich do pierwszego czytania, zatem nie były one nawet przedmiotem debaty. Wszystkie projekty kładły nacisk na kwestie praw, których obecnie pary homoseksualne są pozbawione. Są to przede wszystkim:

- prawo do otrzymywania informacji o stanie zdrowia partnera/partnerki;

- prawo do otrzymywania informacji i decydowania o sobie nawzajem w sytuacji zagrożenia zdrowia i życia;

- prawo i jednocześnie obowiązek pochówku zmarłego partnera/partnerki;

- prawo do wejścia w najem lokalu po zmarłym partnerze/partnerce;

- zwolnienie z płacenia podatku od darowizny otrzymanej od partnera/partnerki oraz od spadku po zmarłym partnerze/partnerce;

- prawo do otrzymywania świadczeń socjalnych po zmarłym partnerze/partnerce oraz do odszkodowania w przypadku jego/jej śmierci;

- prawo do wspólnego rozliczania podatku;

- prawo do zawarcia wspólnoty majątkowej ${ }^{12}$.

Pytania o stosunek do związków partnerskich zadawano respondentom badania „Rodziny z wyboru”13. Spośród 2977 pytanych osób, tworzących pary jednopłciowe, $75 \%$ zadeklarowało, że w razie możliwości sformalizowałoby swój związek. Jedynie 5,1\% badanych nie wyraziło takiej chęci. Powody, dla których respondenci chcieliby oficjalnie zawrzeć związek, dotyczyły głównie praktycznych ułatwień życia codziennego: odbioru listów, wspólnych rozliczeń podatkowych, objęcia ubezpieczeniem zdrowotnym itp. Niemal równie ważna była możliwość materialnego zabezpieczenia siebie lub partnera/ki na wypadek śmierci. Nieco mniej istotne (choć też przez większość uznane za ważne) okazały się dwie pozostałe kwestie: chęć okazania partnerowi/partnerce dowodu trwałości miłości i zaangażowania oraz spowodowanie uznania związku przez rodzinę i otoczenie. Respondenci proszeni o wskazanie trudnych sytuacji będących konsekwencją pozostawania $\mathrm{w}$ nieuznawanym prawnie związku przytaczali zarówno przykłady codziennych problemów, jak i dramatycznych wypadków związanych z zagrożeniem zdrowia i życia najbliższej osoby. Jedna $\mathrm{z}$ badanych kobiet podsumowała swoją historię z wypadkiem partnerki w następujący sposób:

[...] lesbijki i geje, żeby doprosić się o godne traktowanie w tego typu sytuacjach, w homofobicznych instytucjach i wobec homofobów, muszą mieć jakąs prawną podkładkę, papiery, których się nie wymaga od heteryków $[\ldots]^{14}$.

12 http://www.kph.org.pl/zwiazki/ (dostęp: 2.02.2017).

13 J. Mizielińska, M. Abramowicz, A. Stasińska, Rodziny z wyboru w Polsce. Życie rodzinne osób nieheteroseksualnych, Warszawa 2014.

${ }^{14}$ Ibidem, s. 81. 
Jeszcze większe problemy wynikające z braku prawa do sformalizowania związku mają pary jednopłciowe wspólnie wychowujące dzieci. Rodzic niebiologiczny z formalnego punktu widzenia jest dla dziecka obcą osobą — nie może podejmować żadnych decyzji wychowawczych, edukacyjnych, zdrowotnych. Nie jest uznawany za opiekuna dziecka przez żadne instytucje. Prawo do zawarcia związku partnerskiego i pozycja formalnego/formalnej partnera/partnerki biologicznego rodzica z pewnością mogłyby ułatwić funkcjonowanie wielu rodziców społecznych.

\section{Prawo do rzetelnej edukacji}

Hasło dotyczące prawa do rzetelnej edukacji związane jest $\mathrm{z}$ postulatem dostarczania wiedzy na temat mniejszości seksualnych, zgodnej z aktualnym stanem nauki. Chodzi tu przede wszystkim o instytucje edukacyjne i ich programy nauczania. Organizacje LGBT od lat postulują wprowadzenie elementów edukacji antydyskryminacyjnej do szkół, z wyraźnym uwzględnieniem aspektu orientacji psychoseksualnej. Monitorują też postawy nauczycieli wobec potrzeby takiej edukacji. W jednym $z$ badań sygnowanych przez Kampanię Przeciw Homofobii nauczyciele pytani o to, na jakich lekcjach powinna być poruszana tematyka homoseksualności, w większości przypadków $(78,2 \%)$ wybierali wychowanie do życia $\mathrm{w}$ rodzinie ${ }^{15}$. Tymczasem przedmiot ten nie jest obowiązkowy i w praktyce niewielu uczniów bierze w nim udział. Problemem jest też jakość podręczników do tego przedmiotu. Magdalena Chustecka dokonała analizy treści trzech podręczników oraz ośmiu zeszytów ćwiczeń akredytowanych przez Ministerstwo Edukacji Narodowej ${ }^{16}$. Spośród zamieszczanych w nich definicji homoseksualności żadna nie jest zgodna z definicjami przyjętymi we współczesnym dyskursie naukowym. Orientacja seksualna utożsamiana jest jedynie z popędem płciowym. Homoseksualność i/lub biseksualność traktuje się jako: zaburzenie, problem z tożsamością płciową, zniekształcenie. W części podręczników znajdują się informacje na temat możliwości zmiany orientacji homoseksualnej za pomocą terapii reparatywnej (tzw. leczenia homoseksualizmu). Ignorowany jest fakt, iż Amerykańskie Towarzystwo Psychiatryczne i Światowa Organizacja Zdrowia wykreśliły homoseksualizm z klasyfikacji chorób i zaburzeń zdrowotnych. W podręcznikach pojawiają się bardzo stereotypizujące tezy, na przykład wyjaśnienie homoseksualnej orientacji jako między innymi „trudności w identyfikacji z własną płcią przejawiane przez chłopców nadmiernie wrażliwych,

15 J. Świerszcz, Postawy i potrzeby kadry szkolnej wobec tematyki homofobii i homoseksualności. Analiza wyników z badania ankietowego i wywiadów, [w:] Lekcja równości. Postawy i potrzeby kadry szkolnej wobec homofobii w szkole, red. J. Świerszcz, Warszawa 2012, s. 25.

16 M. Chustecka, Analiza podręczników i podstawy programowej - przedmiot wychowanie do życia $w$ rodzinie, [w:] Wielka nieobecna - o edukacji antydyskryminacyjnej w systemie edukacji formalnej $w$ Polsce, red. M. Abramowicz, Warszawa 2011. 
delikatnych, łagodnych i wykazujących zdolności artystyczne"17. W jednej z książek homoseksualizm jest zaliczany do najważniejszych czynników wpływających na szerzenie się chorób przenoszonych drogą płciową. Analizowane podręczniki są jednoznacznie heteronormatywne - jedyna prezentowana w nich wizja rodziny to heteroseksualne małżeństwo z dziećmi. Autorzy, pisząc o homoseksualności, cytują stanowisko Kościoła katolickiego wobec osób o „kondycji homoseksualnej”, traktując je jako źródło wiedzy i wskazówkę postępowania. Znamienne jest też to, że bezpośrednio po fragmentach dotyczących homoseksualności umieszczone są zagadnienia związane między innymi z pedofilią, kazirodztwem i ekshibicjonizmem.

W 2013 roku opublikowany został raport „Szkoła milczenia. Przegląd treści szkolnych podręczników do biologii, WOS i WDŻR pod kątem przedstawienia w nich problematyki LGBTQ i treści homofobicznych". Czterech badaczy analizowało podręczniki z różnych perspektyw. Zbigniew Lew-Starowicz z punktu widzenia seksuologii stwierdzał:

\footnotetext{
Poddane ocenie podręczniki zawierały rozmaite niedoskonałości, a nawet błędy merytoryczne w odniesieniu do ukazywania problematyki LGBTQ, które powinny zostać skorygowane. [...] Co więcej, niektóre prace przedstawiały omawianą problematykę w całości bądź w poszczególnych fragmentach w sposób wyraźnie inspirowany światopoglądowo. Na ogół współwystępowało to licznymi błędami merytorycznymi ${ }^{18}$.
}

Jacek Kochanowski, analizując podręczniki z punktu widzenia gender studies, przytaczając treści patologizujące homoseksualność i ujmujące ją z perspektywy norm religijnych, podsumował to następująco:

Dopuszczenie do użytku szkolnego tego rodzaju treści uważam za skandal. Oczywiście nie mają one żadnego uzasadnienia naukowego, są jedynie wyrazem katolickiej etyki seksualnej i ich jedynym skutkiem może być utrwalenie antyhomoseksualnych stereotypów i uprzedzeń, a co za tym idzie legitymizowanie homofobii i aktów nienawiści ${ }^{19}$.

Dwaj pozostali autorzy raportu, Krzysztof Wąż i Robert Kowalczyk, również wskazywali wiele uchybień i nieprawidłowości w analizowanych podręcznikach. Nawet jeżeli nie zawierały one wyraźnych merytorycznych błędów, pisane były z pozycji wyraźnie heteronormatywnych. W części podręczników znajdowały się informacje niezgodne $\mathrm{z}$ aktualnymi ustaleniami nauki. Przede wszystkim dotyczyły one przyczyn homoseksualizmu - wymieniano tu głównie czynniki środowiskowe: nieprawidłowe relacje rodzinne, uwiedzenie przez osobę homoseksualną czy też brak akceptacji płciowości dziecka. Podobny charakter miały

17 Ibidem, s. 243.

18 Z. Lew-Starowicz et al., Szkoła milczenia. Przegląd treści szkolnych podręczników do biologii, WOS $i$ WDŻR pod kątem przedstawienia w nich problematyki LGBTQ i treści homofobicznych, Toruń 2013, s. 75.

19 Ibidem, s. 84. 
informacje traktujące homoseksualizm jako „problem”, który można wyleczyć dzięki odpowiedniej terapii.

Oprócz przekazywania konkretnych informacji związanych z problematyką orientacji seksualnej szkoły mogą być też miejscem edukacji antydyskryminacyjnej. Z badań prowadzonych w ramach projektu „Wielka nieobecna” wynika, iż kwalifikacje do prowadzenia takiej edukacji nie należą do wymogów kształcenia pedagogów ${ }^{20}$. W związku z tym zależna jest ona wyłącznie od dobrej woli i poziomu świadomości nauczycieli. Prowadzone przez Kampanię Przeciw Homofobii szkolenia wśród nauczycieli, uwrażliwiające ich na problematykę dyskryminacji i dostarczające wzorców do prowadzenia konkretnych zajęć, od początku spotykają się z głosami sprzeciwu. Jednym ze znamiennych głosów na ten temat była wypowiedź prof. Aleksandra Nalaskowskiego, wykładowcy Wydziału Nauk Pedagogicznych UMK w Toruniu, który plany szkoleń skomentował słowami:

Jest to dla mnie ukrytym szukaniem rynku zbytu na usługi homoseksualne dorosłych wśród dzieci. Nie jest to żadna „kampania przeciw homofobii”, tylko pokazywanie, że „gej jest OK”. Jest to PR, który ma przekonać, że warto być gejem. Jest to prześladowanie zdrowej większości społecznej ${ }^{21}$.

\section{Prawo do ochrony przed dyskryminacją i mową nienawiści}

W Konstytucji RP brakuje bezpośredniego odniesienia do orientacji seksualnej w artykule o zakazie dyskryminacji. Zakaz dyskryminacji osób homoseksualnych w zatrudnieniu znajduje się w kodeksie pracy. Ustawa z dnia 3 grudnia 2010 r. o wdrożeniu niektórych przepisów Unii Europejskiej w zakresie równego traktowania jako jeden z czynników dyskryminacji wymienia orientację seksualną. Jednak orientacja seksualna jest przesłanką obejmującą ochronę w najwęższym zakresie - związanym z zatrudnieniem i pracą. Takie obszary, jak: zabezpieczenie społeczne, opieka zdrowotna, oświata czy dostęp do usług nie zostały objęte zakazem dyskryminacji ze względu na orientację.

Organizacje LGBT systematycznie monitorują sytuację osób nieheteroseksualnych w kontekście dyskryminacji. Z najnowszego raportu za lata 2010 i 2011 wynika, iż spośród 11144 przebadanych osób LGBT 12\% było ofiarami przemocy fizycznej, a $44 \%$ - psychicznej, związanej z ich orientacją ${ }^{22}$. Osoby deklarujące doświadczanie przemocy najczęściej wskazywały, iż było to potrącanie, uderzenie,

${ }_{20}$ M. Chustecka, Standardy kształcenia i doskonalenia nauczycieli. Analiza rozporządzeń, [w:] Wielka nieobecna...

${ }^{21} \mathrm{http}$ ://www.piotrskarga.pl/prof--nalaskowski---rdquo-to-ukryte-szukanie-rynku-zbytu-na-uslugi-homoseksualne-doroslych-wsrod-dzieci-rdquo-,3575,i.html (dostęp: 1.02.2017).

${ }^{22}$ M. Abramowicz, Sytuacja społeczna osób bi-i homoseksualnych. Analiza danych $z$ badania ankietowego, [w:] Sytuacja społeczna osób LGB. Raport za lata 2010 i 2011, red. M. Makuchowska, M. Pawlęga, Warszawa 2012. 
szarpanie albo kopanie $(65,2 \%)$ oraz zaczepki seksualne naruszające nietykalność cielesną (41,7\%). Przemoc psychiczna polegała najczęściej na: zaczepkach słownych/agresji słownej $(67,3 \%)$, obrażaniu, poniżaniu, ośmieszaniu $(51,3 \%)$ oraz rozpowszechnianiu negatywnych opinii $(47,6 \%)$. Istotnym zjawiskiem jest to, iż niemal 90\% respondentów deklarujących doświadczenia związane z byciem ofiarą przemocy fizycznej nie składało doniesień na policję, a w wypadku przemocy psychicznej - 97\%. Pytani o powody braku zgłoszeń respondenci najczęściej zaznaczali odpowiedzi: „nie czułam/czułem takiej potrzeby” (57,2\%), „nie wierzę w skuteczność policji w tego typu sprawach” (41,5\%) oraz „obawiałem/ obawiałam się, że policja nie potraktuje mojej sprawy poważnie" (25,7\%). Wśród ofiar przemocy związanej z orientacją seksualną wyraźny jest zatem brak zaufania wobec funkcjonariuszy policji.

W przypadku postulowanego prawa do ochrony przed mową nienawiści problemem jest brak jednoznacznej definicji tego zjawiska, co utrudnia ściganie go jako przestępstwa. Ogólne definicje znajdują się w rekomendacjach Komitetu Ministrów Rady Europy, ale polskie prawo ich nie uwzględnia. W Kodeksie karnym istnieje zapis mówiący, że znieważanie lub nawoływanie do nienawiści na tle narodowościowym, rasowym, etnicznym, wyznaniowym jest zabronione i karalne. Znieważana osoba homoseksualna nie może liczyć na taką samą ochronę jak członkowie mniejszości narodowych, etnicznych czy wyznaniowych. Dlatego też działacze LGBT wykazują, iż ochrona prawna członków mniejszości seksualnych jest wciąż niewystarczająca. Nieprecyzyjne lub zbyt ogólne zapisy sprawiają, że osoby oskarżane o dyskryminację są uniewinniane. Ilustracją tego może być przypadek uniewinnienia Ryszarda Fałka (zastępcy prezydenta Radomia) oraz warunkowego umorzenia postępowania wobec Sławomira Adamca (radnego), oskarżanych o zniesławianie osób homoseksualnych swoimi publicznymi wypowiedziami. Sąd uznał, iż:

[...] oskarżyciel prywatny nie mógł wnieść aktu oskarżenia, bo art. $212 \$ 2 \mathrm{kk}$ chroni m.in. „grupy osób”, a osób homoseksualnych jako takich nie można uznać za „grupę osób”. Zdaniem sądu są one "grupą ludności” i ochrona $\mathrm{z}$ w/w przepisu im nie przysługuje ${ }^{23}$.

W 2014 roku Centrum Badań nad Uprzedzeniami UW i Fundacja Batorego opublikowały badania dotyczące akceptacji mowy nienawiści wobec wybranych zbiorowości społecznych. Spośród sześciu mniejszości społecznych to właśnie obraźliwe sformułowania odnoszące się do osób nieheteroseksualnych spotkały się z największym przyzwoleniem, na przykład stwierdzenie: „Brzydzę się pedziów, są wynaturzeniem człowieczeństwa, powinni się leczyć" co piąty respondent uznał za dopuszczalne w przestrzeni publicznej ${ }^{24}$.

${ }^{23}$ K. Śmiszek, P. Szczepłocki, Ochrona prawna LGBT nadal niewystarczająca, [w:] Sytuacja społeczna osób LGBT..., s. 183.

24 M. Bilewicz et al., Mowa nienawiści. Raport z badań sondażowych, Warszawa 2014, s. 76. 
Publiczne dyskredytowanie osób nieheteroseksualnych we współczesnym dyskursie publicznym zyskało nowy wymiar - wiąże się bowiem $\mathrm{z}$ wykorzystywaniem w sporach ideologicznych pojęcia „gender”. W ramach tego dyskursu politycy, publicyści czy duchowni wygłaszają różnorodne homofobiczne stwierdzenia (np. porównywanie homoseksualizmu do nekrofilii, pedofilii, zoofilii), tłumacząc to koniecznością walki z tzw. ideologią gender i nie ponosząc za to konsekwencji. Działacze LGBT od lat domagają się skuteczniejszej ochrony przed nienawiścią wobec osób nieheteroseksualnych w Kodeksie karnym oraz przyjęcia kompleksowego ustawodawstwa antydyskryminacyjnego. Do tej pory jednak ich starania nie odniosły skutku. Przyzwolenie na homofobię w dyskursie publicznym współistnieje ze społecznymi postawami. Z raportu drugiej edycji Polskiego Sondażu Uprzedzeń przeprowadzonego przez Centrum Badań nad Uprzedzeniami przy Wydziale Psychologii Uniwersytetu Warszawskiego wynika, że negatywne postawy wobec osób homoseksualnych są obecnie bardzo wyraźne ${ }^{25}$. Spośród reprezentatywnej próby 965 dorosłych Polaków 29\% zgodziło się ze stwierdzeniem: „Osoby homoseksualne stanowią zagrożenie dla wszystkiego, co uważam za dobre, moralne i normalne w społeczeństwie”; $35 \%$ respondentów uznało, iż „,osoby homoseksualne zagrażają polskiej rodzinie”, $36 \%$ zaś poparło zdanie: „Jeśli osoby homoseksualne zdobędą większe prawa, odbędzie się to naszym kosztem”.

\section{Zakończenie}

Działacze polskiego ruchu LGBT twierdzą, że geje i lesbijki w Polsce to wciąż obywatele „drugiej kategorii” ${ }^{26}$. Takie opinie związane są przede wszystkim z tym, iż w ciągu kilkudziesięciu lat funkcjonowania oficjalnych organizacji ich działaczom nie udało się wywalczyć realizacji podstawowego prawa, czyli prawa do zawierania związków. Bez względu na to, czy u władzy były partie prawicowe czy lewicowe, ich rządy nic w tej kwestii nie zmieniały. Różnice pomiędzy nimi polegały głównie na przedwyborczych deklaracjach. O ile na przykład przedstawiciele PiS zazwyczaj jasno prezentowali swój negatywny stosunek wobec mniejszości seksualnych, o tyle politycy SLD oraz Platformy Obywatelskiej przedstawiali obietnice poparcia postulatów środowisk LGBT, z których następnie nic nie wynikało i kolejne propozycje ustaw trafiały do sejmowego kosza. Dominujące strategie polityczne od lat bowiem opierają się na przeświadczeniu, że lepiej nie podejmować żadnych działań niosących zagrożenie „narażenia się” konserwatywnemu elektoratowi oraz biskupom Kościoła katolickiego. W takiej wersji politycznego

25 P. Górska, M. Mikołajczak, Postawy wobec osób homoseksualnych, Warszawa 2014, http://cbu. psychologia.pl/uploads/f_winiewski/PPS2\%20raporty/Postawy\%20wobec\%20os\%C3\%B3b\%20homoseksualnych\%20PG\%20MM\%20ST\%20poprawiony.pdf (dostęp: 2.02.2017).

${ }^{26}$ Zob. np. M. Kurc, Mąż i mąż. Śmieszne?, http://www.krytykapolityczna.pl/Opinie/KurcMazimazSmieszne/menuid-431.html (dostęp: 2.02.2017). 
koniunkturalizmu prawa człowieka oraz prawa obywatelskie mają drugorzędne znaczenie. Obecne rządy Prawa i Sprawiedliwości różnią się od poprzednich rządów tym, że politycy jasno deklarują swój sprzeciw wobec realizacji postulatów ruchu LGBT. W poprzedniej kadencji Sejmu SLD, Twój Ruch i PO złożyły projekty ustawy o mowie nienawiści. Dotyczyły one ścigania przestępstw popełnionych z nienawiści, między innymi ze względu na płeć, tożsamość płciową czy orientację seksualną. Na początku 2016 roku Ministerstwo Sprawiedliwości, udzielając odpowiedzi na pytania dziennikarzy, poinformowało, że obecnie nie trwają i w ogóle nie są planowane prace nad takimi projektami ustaw.

Pobieżny przegląd doniesień medialnych związanych z aktywnością obecnie rządzących polityków stanowi jednoznaczną ilustrację ich stosunku wobec mniejszości seksualnych. Przykładowo: posłanka PiS, Barbara Bubula, zarzuciła telewizyjnym wiadomościom „propagowanie homoseksualizmu”. Zarzut dotyczył materiału na temat ustaw regulujących na świecie jednopłciowe związki partnerskie, w którym posłanka dostrzegła niewłaściwe według niej „obrazki pary gejów z pieszczotliwie splecionymi dłońmi"27. Minister Nauki i Szkolnictwa Wyższego, Jarosław Gowin, zapowiedział konieczność usunięcia z rankingów czasopism naukowych ,jakichś studiów gejowskich lub lesbijskich”28. Ministerstwo Środowiska wycofało z emisji spoty poświęcone segregacji śmieci. Powodem decyzji był udział w nich Macieja Nowaka - krytyka teatralnego i krytyka kulinarnego o orientacji homoseksualnej. Wiceminister środowiska argumentował to następująco:

[...] my nie musimy tego ukrywać, że osoby, które biorą udział w tym spocie [...] są jednak w pewnym ruchu, który promuje ideologię, która jest jakby sprzeczna $\mathrm{z}$ tradycją i jest to ideologia gender. Ona w miękki sposób jest tutaj lokowana ${ }^{29}$.

Znamienna dla strategii i działań partii rządzącej jest też wypowiedź posła PiS, Stanisława Pięty, który w rozmowie z jedną ze stacji telewizyjnych stwierdził, że:

[...] prawa człowieka nie istnieją. Istnieją obowiązki człowieka i lepiej definiować człowieka poprzez jego obowiązki. Wtedy te rzekome prawa nigdy nie będą naruszane [...] Pięta dodał również, że człowiek ma przede wszystkim obowiązki, a prawa to jest jakieś urojenie człowieka ${ }^{30}$.

27 https://www.tvp.info/23385721/poslanka-bubula-zarzucila-wiadomosciom-propagande-tematyki-gejowskiej (dostęp: 3.02.2017).

28 http://wiadomosci.dziennik.pl/polityka/artykuly/505753,jaroslaw-gowin-o-reformie-nauki-i-szkolnictwa-wyzszego-likwidacja-studiow-gejowskich.html (dostęp: 3.02.2017).

29 http://www.tvn24.pl/wiadomosci-z-kraju,3/ministerstwo-srodowiska-wycofalo-spoty-z-maciejem-nowakiem,613014.html (dostęp: 2.02.2017).

30 http://www.rp.pl/Prawo-i-Sprawiedliwosc/160219428-Pieta-Prawa-czlowieka-nie-istnieja. html\#ap-1 (dostęp: 2.02.2017). 


\section{Bibliografia}

Abramowicz M., Sytuacja społeczna osób bi-i homoseksualnych. Analiza danych z badania ankietowego, [w:] Sytuacja społeczna osób LGBT. Raport za lata 2010 i 2011, red. M. Makuchowska, M. Pawlęga, Warszawa 2012.

Bell D., Binnie J., The Sexual Citizen: Queer Politics and Beyond, Cambridge 2000.

Bilewicz M., Marchlewska M., Soral W., Winiewski M., Mowa nienawiści. Raport z badań sondażowych, Warszawa 2014.

Chustecka M., Analiza podręczników i podstawy programowej - przedmiot wychowanie do życia $w$ rodzinie, [w:] Wielka nieobecna - o edukacji antydyskryminacyjnej w systemie edukacji formalnej $w$ Polsce, red. M. Abramowicz, Warszawa 2011.

Górska P., Mikołajczak M., Postawy wobec osób homoseksualnych, Warszawa 2014, http://cbu.psychologia.pl/uploads/f_winiewski/PPS2\%20raporty/Postawy\%20wobec\%20os\%C3\%B3b\%20 homoseksualnych\%20PG\%20MM\%20ST\%20poprawiony.pdf.

Kurc M., Mąż i mąż. Śmieszne?, http://www.krytykapolityczna.pl/Opinie/KurcMazimazSmieszne/ menuid-431.html.

Lew-Starowicz Z., Kochanowski J., Wąż K., Kowalczyk R., Szkoła milczenia. Przegląd treści szkolnych podręczników do biologii, WOS $i$ WDŻR pod kątem przedstawienia w nich problematyki LGBTQ i treści homofobicznych, Torun 2013.

Mizielińska J., Abramowicz M., Stasińska A., Rodziny z wyboru w Polsce. Życie rodzinne osób nieheteroseksualnych, Warszawa 2014.

Plummer K., Intimate Citizenship: Private Decisions and Public Dialogues, Seattle-London 2003.

Pudzianowska D., Obywatelstwo w procesie zmian, Warszawa 2013.

Richardson D., Constructing sexual citizenship: theorizing sexual rights, „Critical Social Policy” 20, 2000, nr 1.

Richardson, D. Rethinking Sexuality, London-New Delhi 2000.

Śmiszek K., Szczepłocki P., Ochrona prawna LGBT nadal niewystarczajaca, [w:] Sytuacja społeczna osób LGBT. Raport za lata 2010 i 2011, red. M. Makuchowska, M. Pawlęga, Warszawa 2012.

Świerszcz J., Postawy i potrzeby kadry szkolnej wobec tematyki homofobii i homoseksualności. Analiza wyników z badania ankietowego i wywiadów, [w:] Lekcja równości. Postawy i potrzeby kadry szkolnej wobec homofobii w szkole, red. J. Świerszcz, Warszawa 2012.

Tomasik K., Gejerel. Mniejszości seksualne w PRL-u, Warszawa 2012.

Warner M., Introduction, [w:] Fear of a Queer Planet, red. M. Warner, Minneapolis 1993.

Wilson A., The transnational geography of sexual rights, [w:] Truth Claims: Representation and Human Rights, red. M.P. Bradley, P. Petro, New Brunswick 2002.

\section{Sexual minorities' rights in Poland}

\section{Summary}

The article covers actions of Polish LGBT movement and the situation of non-heterosexual people in Polish society. These issues are put in a context of problematics of civil rights, part of which sexual rights are. The introduction to the article serves as a short presentation of the concept of sexual citizenship. Afterwards, the history of LGBT activists' organisational work in Poland is outlined, here presented as a fight for three fundamental rights: right to form registered partnerships, right to thorough education and right to protection against discrimination and hate speech. For over 25 years those demands remain intact, since none of these rights has been guaranteed to sexual minorities yet. 